\title{
Classroom management in Japanese EFL classrooms
}

\section{Keiko Sakui \\ Kobe Shoin Women's University, Japan}

The problems of classroom management in many academic subjects are an important area of research in general education in many countries (Doyle, 1990; Jones, 1996; Kagan, 1992; Tauber, 1999). Compared to the level of interest in the field of general education, not enough attention is paid to classroom management issues in language classrooms, and in particular there is little empirical research on classroom management in English as a Foreign Language (EFL) in Japan. To fill the gap, this study will report on: a) classroom management difficulties that arise in Japanese EFL classrooms when teachers try to teach English communicatively, b) how teachers conceptualize and attempt to deal with these problems, and c) what strategies can be offered to alleviate these problems.

教室内における指導運営はどの国においても重要な課題である。このテーマについてこ れまで多くの研究が行われてきたが (Doyle, 1990; Jones, 1996; Kagan, 1992; Tauber, 1999)、 言語教育の分野では実証研究がほとんぞ行わ机ていないと言ってもよく、日本の英語教育 界ではさらに関心が低いように思わ机る。本論文は、a) 英語をコミュニケーションの手段 として指導しようとする場合には特に運営指導が難しくなること、b) 教員はこのような困 難に直面した場合どのように対処しているのか、c) 効果的な対象方略とはどのようなもの か、これら 3 点について実地調査の報告を行った。

\section{Classroom Management}

Classroom management has been an important area of discussion and research in general education for quite some time. Researchers claim that, in order to achieve effective instruction, teachers need to possess two types

JALT Journal, Vol. 29, No. 1, May, 2007 
of knowledge: knowledge of subject matter and knowledge of classroom management (Kagan, 1992). Doyle (1986) uses the term hidden curriculum to portray the importance of classroom management, arguing that the school curriculum consists not only of an academic curriculum but also of a hidden agenda of classroom management. Classroom management tends not to be foregrounded in discussions of curricular issues, but it plays a significant role in ensuring learning, because the classroom is a setting for complex interactions and negotiations among teacher and students. It is also where different factors, such as learner motivation, student interests, or different levels of competence, are at work. It is this complexity that makes smooth classroom management so challenging (Doyle, 1986).

Basing his conclusions on the results of a meta-analysis of education research, Jones (1996) claims that teachers see classroom management as one of the most important aspects of their work. Research based on teachers' interviews further suggests that when classroom management becomes difficult, it can be a cause of teacher burnout and loss of selfesteem (Brouwers \& Tomic, 2000). Classroom management might be considered to pertain only to disciplinary issues, but most researchers define it in broader terms, including the planning of instruction, the management of learners, the process of decision-making by teachers, and the construction and maintenance of teacher-student relationships (Doyle, 1986; Fenwick, 1998; Jones \& Vesilind, 1995). Doyle (1990) argues that classroom management is a means to ensure "order" in classrooms:

To say a classroom is orderly, then, means that students are cooperating in the program of action defined by the activity a teacher is attempting to use. Misbehaviour, in turn, is any action by students that threatens to disrupt the activity flow or pull the class toward an alternative program of action. (p. 115)

Following this broad definition of classroom management, the focus of this paper will not rest solely upon what constitutes bad behaviour, but will rather expand to include teacher reactions to, and understanding of, such behaviour.

\section{Classroom Management and English Education in Japan}

Classroom management issues are recognized as a serious educational and societal problem in Japan; however, there is very little empirical research available that addresses these issues. This section will report on 
one of the few studies available on this topic in general education. The focus will then be narrowed to examine the current state of EFL education in Japan. Japanese teachers of English have to satisfy two academic goals: preparing students for grammar-skewed entrance examinations and fostering communicative skills. How they struggle to carry out and balance these two goals will be described.

\section{Classroom Management Problems in Japan}

In spite of society's awareness of classroom management problems, and the fact that books on "how to solve management issues" are available to teachers (Kawamura, 1999; 2000), few empirical studies have been conducted in Japanese contexts (Kato, 2001; Ran, 2001). One of the few is a survey study that collected data from 203 primary school teachers, 109 middle school teachers, and 54 high school teachers across all subjects exploring the teachers' perceptions of classroom management (Wakazono, 2001). Overall $25 \%$ of the respondents experienced some type of classroom management problem, with the middle school teachers reporting the highest rate $(32.1 \%)$.

The participants were allowed to choose multiple responses and the results listed several phenomena that characterise classroom management difficulties. They include: a) students walking in and out of the classroom $(74 \%), \mathrm{b})$ students not stopping talking $(62.2 \%)$, c) students not listening to the teacher's instruction(s) or advice (59\%), d) students suddenly screaming or throwing things $(55.7 \%)$, and, e) students not sitting down when the class begins $(28.7 \%)$.

The results also reveal teachers' perceptions of possible causes of management problems. These are a) an increase in the number of children who are not disciplined by their parents at home $(77 \%), b)$ a decline in the quality of education at home $(71.9 \%), \mathrm{c}$ ) a decline in the quality of teachers $(51.1 \%)$, and d) children's psychological problems and stress $(45.1 \%)$. The study reveals that teachers are confused and do not have clear ideas as to how to improve the situation. When asked for possible remedial procedures, the need for smaller class sizes was the only suggestion mentioned by a considerable number of teachers $(24.6 \%)$.

\section{English Education System in Japan}

A large proportion of English teaching at the secondary school level is done through grammar-translation methods (Gorsuch, 1998). However, 
as a result of the influence of recent language acquisition theories that have been developed mainly in Western countries, and also as a result of an increasing interest in Japan of encouraging children to communicate in English, teaching styles which incorporate some principles of communicative language teaching (CLT) have gradually gained entry into Japanese secondary English classrooms (Sakui, 2004).

Attempts to alter English education in Japan towards a more communicative approach began about twenty years ago. In 1986, the government started the Japan Exchange and Teaching (JET) Program, in which Japanese secondary school students receive occasional lessons with a native speaker English teacher who team teaches with a Japanese teacher. The exposure to these native speaker teachers is, however, still minimal and the system is not free from criticism (McConnell, 2000), especially concerning the lack of training for the native speaker English teachers and the lack of collaboration between them and the Japanese teachers. More recently the Japanese national level curriculum guide issued by the government states that fostering communicative abilities in English is the primary goal of English education (Monbukagakusho, 1999).

Given this background it is easy to see why Japanese teachers of English feel they are caught in a dilemma to try to ensure two separate types of instruction (Mulvey, 1999; Sakui, 2004). The teachers feel responsible for preparing students for grammar-skewed entrance examinations, and at the same time they feel pressured to teach English communicatively in order to satisfy the new guidelines. While the teachers face the challenge of meeting two separate instructional goals, they also have to deal with an increasing number of classroom management problems.

\section{The Study}

In order to investigate teachers in a specific cultural context, all the participants chosen for this research were members of a self-study group consisting of 30 Japanese teachers of English. The organization usually met on weekends and was run by the teachers themselves, with senior members giving training to younger members of the organization. Occasionally they invited outside speakers to talk about further education for teachers, with a concentration on knowledge about language education and second language acquisition. Sato (1994) and Shimahara (1998) point out that there are many such self-initiated study groups among Japanese teachers. Indeed, Sato claims that more than $53 \%$ of Japanese teachers belong to one or another of these types of groups in order to receive further 
training from their peers. Sato herself participated in such a group, which met once a month on weekends from 2 p.m. to 9 p.m. This is very similar to the group that I observed. The main data for this report comes from a year-long ethnographic study of three metropolitan-area teachers who participated in my study group: Ms. Kase, Ms. Hamada, and Ms. Tsuda. (All the names of people and institutions in this study are pseudonyms to protect the teachers' and students' privacy.)

At the time of the study, Ms. Kase was in her early 40s and had been a public junior high school teacher for 19 years. She was single and lived at home with her family. Her school was located in a blue-collar, low-income neighbourhood. Ms. Tsuda was in her late 30s and had been a high school English teacher for 15 years. She was also single, and had recently entered a Master's program in TESOL at a satellite school of an American university. Ms. Hamada had turned 30 years old, and had just married another school teacher. She had been teaching English at the junior high school level for eight years.

Starting in April 2001, I conducted participant observations and interviews with Ms. Kase and Ms. Tsuda for one academic year, and with Ms. Hamada for 6 months. (Since Ms. Hamada had some difficulty in managing her class during that time, she terminated participation after 6 months.) I visited each school once a week, and usually observed two to three 50-minute class periods per day. In addition, between August 2000 and March 2002, I conducted interviews (lasting two hours on average) with 15 other teachers in this self-study group, whose classes I could not observe. These teachers were selected following "purposeful sampling" principles (Patton, 1990, p. 169), meaning that types of participants were selected to include as wide a range of factors as possible that could influence teachers' beliefs and practices. The three main participants were all female and did not have any children. For the 15 additional selected interviewees, I included male participants, teachers with shorter or longer teaching experience, and teachers who had children.

All the interviews were conducted in Japanese, audiotaped, transcribed, and translated into English. In order to preserve the nuance of these teachers' voices, I translated their utterances as closely as possible, which at times did not necessarily meet standard English language rules. I collected and analysed data by adopting an inductive process, following the procedures commonly employed in "grounded theory" studies (Strauss \& Corbin, 1998). Adopting a "funnel" approach typical of qualitative research, I initially went into the research field with a very broad research interest: teachers' beliefs and practices. At the beginning of the 
study I did not have specific research topics in mind. Therefore, my initial observation notes were filled with whatever I could see and hear in the schools, and my interview questions were about the teachers' experiences and teaching beliefs in general. Over time, by reviewing these notes and interview excerpts, I narrowed down my research interest to three topics that I decided to investigate further, one of which was classroom management. The later stages of my observation focus and interview questions were more specifically related to these topics. Since the research adopted a qualitative methodology, the findings are not meant to be generalized, but readers are encouraged to find resonance in what is described and claimed.

\section{Results}

This section reports two main findings: a) the teachers' struggle to balance communicative language teaching and classroom management, and b) a summary of how the teachers conceptualize and tackle the classroom management problems that they face.

\section{Balancing Communicative Language Teaching and Classroom Management}

Conducting communicative language teaching (CLT) whilst managing their classroom was a challenging task for the teachers at times. During the observations, many factors were identified as making classroom management difficult, but CLT activities in particular seemed to make classroom management more challenging than teacher-fronted instruction. The main reasons for this were: a) the spatial arrangement of classrooms, b) changes in students' and teachers' expected roles, and c) increased cognitive demands on students. Each factor is explained in detail below.

\section{Spatial Arrangement of Classrooms}

Many CLT activities require a change in the physical positioning of students and teachers. In teacher-fronted grammar instruction, students are expected to sit in rows facing the front of the classroom, which enables the teacher to supervise the whole class as one group. In contrast, CLT often made the spatial organisation of a classroom very complex. Students were encouraged to walk around the classroom and in order to carry out a task often left their seats to talk to their classmates. Obviously, these tasks gave students far greater mobility and much more freedom 
in their choices of behaviours, which made classroom management more challenging for the teacher. Even in the activities in which students remained seated, they were often instructed to rearrange the desks and chairs in order to form pairs and small groups. The difficulties inherent in these seating patterns contrasted strongly with the ease of managing the entire class as a whole group. In these pair and group work settings, six to eight groups were formed with the students facing each other rather than the teacher. The teacher was expected to manage these different groups simultaneously. Based on my observations, the teachers sometimes had difficulty in managing many groups at the same time. For example, if two or three groups were not on task, the teacher needed to move around the classroom and attend to these groups so that they could get back on track. The teacher's attention often seemed to be consumed in managing these problematic groups and was not focused on academic matters, whereas groups that were on task tended to be left alone and did not receive any encouragement or monitoring of their performance.

\section{Students' and Teachers' Expected Roles}

Students' expected roles and behaviours also changed during CLT activities. In teacher-fronted grammar classes, a student's ideal role was as a silent and attentive listener, but in CLT students' expected roles changed dramatically: they were expected to not only be attentive listeners but also active speakers. In grammar lessons students were trained to be quiet; however, when the activities became more communicative, the students were expected to be more active and to demonstrate their knowledge and opinions vocally.

In CLT, students were held accountable for their performance to a far greater extent than in traditional teacher-fronted grammar teaching. In teacher-fronted teaching, instruction could proceed smoothly even though there were some students who did not fully participate or complete tasks. But in CLT, group or pair work formats heightened the necessity for each student's participation, so a small number of students who were unwilling to participate could potentially halt or jeopardise the instructional process. Teachers often need to reestablish and negotiate students' new roles and expectations of CLT instruction. As teachers can only now and then adopt communicatively oriented activities because of curriculum and entrance examination pressures, the requirement to incorporate CLT techniques into language classes has increased the difficulty of teaching in a Japanese EFL classroom. The sporadic use of CLT 
activities did not provide adequate time and training for the students to learn new roles and behaviours. Furthermore, teachers often did not effectively communicate the nature and expectations of these new roles and behaviours. In other words, the students were expected to change their roles and behaviours accordingly without any explicit training or explanation from the teachers.

\section{Cognitive Complexity of Activities}

Another change that CLT often imposed was to increase the complexity of activity procedures and their goals. In less cognitively demanding activities, such as reading texts aloud, copying texts, and writing translated sentences in their notebooks, there was very little room for students to misinterpret the instructional procedures. However, CLT activities placed greater demands on the students to interpret the activity goals and procedures. The following summary of a lesson from Ms. Kase's class illustrates how the instructional procedures during a CLT activity increased the cognitive demands placed on students. The linguistic goal of this lesson was the production and comprehension of the following exchange (field note, November 6, 2001):

Q: Can you play soccer?

A: Yes, I can / No I can't.

Students received the handout depicted in Figure 1:

\begin{tabular}{|l|c|c|c|c|}
\hline & play soccer & play the guitar & speak English & run fast \\
\hline Bruce & $\mathrm{o}$ & $\mathrm{o}$ & $\mathrm{x}$ & $\mathrm{x}$ \\
\hline Kumi & $\mathrm{x}$ & $\mathrm{x}$ & $\mathrm{o}$ & $\mathrm{x}$ \\
\hline Ken & $\mathrm{x}$ & $\mathrm{x}$ & $\mathrm{o}$ & $\mathrm{o}$ \\
\hline Tom & $\mathrm{x}$ & $\mathrm{x}$ & $\mathrm{o}$ & $\mathrm{x}$ \\
\hline
\end{tabular}

Figure 1. Handout from Ms. Kase's class.

The teacher instructed students to form groups of four by moving their desks. Within each group, each student was expected to assume a role (that is, one student becomes Bruce, one plays Kumi, and so on), 
which took some time for the students to understand. After each student chose their role, one student from each group went to another group and asked questions such as, "Can you play soccer?" and "Can you speak English?" The purpose of this segment was for the students to match the information on the handout with the responses from their classmates in order to identify which role the respondent was playing. This added further cognitive complexity because not only did the student have to select a role from the four names on the handout, but she also had to guess the role of her respondent from the exact same name list. In this example the cognitive demands on the students to understand the activity procedure seemed to exceed the complexity of the target language structure. The class became chaotic because many students were very confused by the procedures. Some students soon started complaining that they did not know what to do and that they did not want to perform the task. In the end, many students stopped participating in the activity altogether.

The three aspects of CLT described in this section-changing spatial arrangements, different expected roles, and increased cognitive demands-can come into conflict with the traditional organisational strategies that teachers employ to ensure order. While teachers were aware that establishing routines while using familiar activities and artefacts was critical in managing a class successfully, teachers needed to depart from these routines and institute new expectations and rules. Since CLT activities were not carried out uniformly in every lesson, and because each CLT activity required slightly different role expectations, this placed demands on both students and teachers to establish a new set of classroom norms. One consequence of the difficulties of classroom management of CLT activities is that, although some teachers said that they believe in the educational outcomes of CLT, in order to ensure classroom order they tended to avoid these types of instructional activities and opted for grammar teaching lessons instead.

\section{Teachers' Perceptions of Classroom Management Difficulties}

All the teachers studied reported that they had either experienced classroom management difficulties or that they knew some other teachers who have had problems. They all agreed that classroom management was not only a problem during CLT lessons, but that it was, in fact, becoming more difficult for several reasons. This section reports on the reasons the teachers give as to why classroom management is becoming more difficult and what strategies they use to tackle problems. 
When I asked why classroom management is becoming increasingly difficult the teachers reported that they could not identify any one single cause. They expressed the belief that it is a complex societal issue that involves teachers and parents, community members, and students. One of the teachers said that the problem was a complex one because it could happen even to an experienced teacher who had not had any previous difficulties. While puzzled, the teachers offered several reasons why they believed classroom management problems are becoming increasingly serious. First, many teachers complained about class size, saying that 40 students in one class is too large a number to manage, and they had strong opinions about the need for smaller classes. The teachers also mentioned that large classes consist of many different types of problem students who tend to cause management difficulties anyway. Teachers reported that some students have trouble at home, making them emotionally and psychologically unstable. Several teachers mentioned that this type of diversity among the student population was reflected in differences among the communities where the students live. Teachers said students in some school districts were easier to teach than others, reflecting the students' and their parents' socioeconomic status. For example, some students come to school with the concept that no matter how boring schoolwork might be, they need to sit and listen to the teacher, whereas other students do not have this mindset. Some teachers clearly felt that there is very little they can do to influence this factor.

In addition to the diversity of students' backgrounds, some teachers reported that students' values and experiences outside schools have changed in recent years. Ms. Kase reported that some students did not have adequate perseverance and were easily discouraged. Ms. Tsuda claimed that the traditional value of respect for schools and teachers was quickly disappearing. She expressed this sentiment by saying that a teacher used to be far more respected in a community and he or she had more authority. However, nowadays parents express more contempt for teachers, saying, "They are only schoolteachers." Mrs. Tanaka also mentioned that she perceived a gap between what students wanted and what schools could offer. She claimed that there is an abundance of information and resources about English language and foreign culture from stimulating sources outside of school, such as recent movies, CDs, and DVDs, while, in contrast, students receive fairly old-fashioned instruction in school, which usually relies on audiotapes.

Another aspect that some teachers reported was the intricacy of power relations between a teacher and her students. Out of the 18 teachers I 
interviewed, 5 reported that they need to demonstrate their power and, when they do so, they need to be persistent. Ms. Fukami said:

Students are aware that if they misbehave, the teacher will point it out or scold them. We, teachers, need to have power to make them feel that way. (Interview, March 26, 2002)

Similarly, Ms. Nagase reported the importance of teachers being firm with students:

We should not compromise. When students ask, "Is it okay to use Japanese?" we need to be persistent and say, "No. Not now." We need to be strong to say that. (Interview, March 20, 2002)

Some teachers also referred to the possibility of taking advantage of peer pressure. Some teachers resorted to asking students for help in classroom management. Ms. Kase said that there was a limit to what a teacher alone could do to influence students and to prevent or eliminate their misbehaviours. She said that the students' power was sometimes greater than the teacher's:

If students do not agree with what we say, classroom management becomes difficult. The influential children in the class have more power than teachers. If 10 students in the class said, "Let's skip this class" and leave the classroom, a teacher can do nothing about it. . . I ask for and try to win their sympathy and empathy. . . If they start to think that if they did this and that, the teacher would feel bad, so they should better stop. We need to win that kind of empathy sometimes. (Interview, December 11, 2001)

As Ms. Kase mentioned, the distribution of power among children clearly influences classroom dynamics. Ms. Sakamoto reported on the importance of the individual student with whom she tries to negotiate power:

I do not try to negotiate power with every student. If there is one student who has power among students, the rest of the students follow him or her in spite of their feelings. So I need to establish a power relationship with this particular student. (Interview, March 19, 2002) 
Ms. Sakamoto further mentioned that avoiding emotional conflicts with students was important. She considered that building trust between a teacher and students was one of the most important aspects of ensuring effective classroom management. A teacher's emotional outbursts risk damaging the students' trust in their teacher.

\section{Discussion}

The purpose of this paper is to describe the challenges of classroom management that Japanese teachers of English experience in their work. This study reveals that these teachers are teaching in a complicated system where students are not necessarily always well behaved. I should note that in the Japanese school system, I observed that regular classroom teachers sometimes needed to attend to their students' psychological and emotional problems during breaks and after school. Also, Japanese schools do not usually have recourse to administrative support, such as sending problematic students to an administrator's office, or implementing punitive measures such as detention. Instead classroom teachers are expected to handle most problems by themselves.

Similarly to the teachers surveyed by Wakazono (2001), the participants in this study made observations about classroom management issues from a wide variety of perspectives. They analysed classroom management issues in terms of students' socioeconomic backgrounds, communities' changing values towards teachers and schools, and discrepancies in available English materials both in and outside classrooms. The teachers further showed a sophisticated understanding of the power negotiations between teachers and students. Many existing studies suggest that the negotiation of power between teachers and students is an important aspect of ensuring successful classroom management (Allen, 1986; Cothran \& Ennis, 1997; Doyle, 1986; Tauber, 1999; Winograd, 2002). Some of the participants in this study understand that power lies not only in the hands of the seemingly powerful (the teacher), but also with the seemingly powerless (the students). The teachers accepted the intricacy of power relations in their classrooms and tried to adopt different strategies to cope with them. However, the teachers in this study appeared to have difficulties in objectively analyzing their own classroom teaching practices from a classroom management perspective. Specifically, they were less articulate in describing exactly in what ways CLT makes classroom management challenging and what they could do to alleviate any problems. 
Reconciling CLT and ensuring successful classroom management is not only a problem for the participants in this study. Previous research in education actually shows that cooperative and progressive teaching styles, which CLT principles are based on, are not used frequently in classrooms across different subjects. Wertsch (1998) argues that studies investigating classroom discourse in different subjects at all levels show that teacher talk takes about two thirds of the classroom time, and sometimes a large portion of this talk is concerned with classroom management. Because language education is geared towards communicatively-oriented teaching, we could argue that language teachers are pressured to make their instruction more communicative and more interactive than other subject teachers, and this poses a greater challenge to them as they attempt to balance this demand with the demands of managing a class.

Communicative forms of teaching might excel in fostering communicative abilities, but they tend to make classroom management more difficult. Lefstein (2002) argues that management issues are incorporated within traditional teacher-fronted teaching. Doyle (1990) argues that the looser the structure of a lesson and the more mobile the students are, the more possibility there is for students" "miseducative" behaviours to occur. Doyle writes, "When students are required to interpret situations and make decisions to accomplish tasks (such as during word problems or essays), activity flow is frequently slow and bumpy. Managing higherorder tasks requires exceptional management skills" (p. 116).

While advocating more progressive communicative language methods, classroom researchers into language teaching seem to have overlooked the reality that this form of instruction makes classroom management inherently difficult. Previous studies in language education also make some reference to the fact that CLT makes classroom management difficult in some teaching contexts (Lee, 1996; Lewis, 2002; Li, 1998; Sato \& Kleinsasser, 1999; Williams \& Burden, 1997), yet there is little research available dealing with classroom management as the central theme of the investigation.

\section{Implications of the Study and Recommendations to Help Improve the Situation}

Although it is impossible to offer quick remedies for this complex issue, the present study identifies a number of areas in teacher education in Japan that need to be addressed. It suggests the strong necessity to establish better quality teacher education, which will provide a sound 
background in teaching methodology and classroom management knowledge and strategies. The lack of such training in Japan is well documented (Lamie, 2000; Okano \& Tsuchiya, 1999). Future teacher training programmes urgently need to promote the view that classroom management is an important part of teacher training, rather than the current belief and practice that these are skills and strategies that teachers tend to develop on their own throughout their professional careers (Winograd, 2005). The participants in this study are mostly experienced language teachers who hold a deep understanding that teaching cannot be separated from various societal factors. This type of knowledge would, no doubt, serve as valuable information to preservice teachers.

The present study further points out that in addition to the need to understand teaching from sociopolitical and cultural contexts, teachers need to train themselves to reflect on their lessons from classroom management perspectives, examining carefully the link between classroom management and the meeting of academic goals. In order to help teachers develop the process of reflection, it would be useful for teachers, both in preservice and inservice training, to have the opportunity to share different aspects of classroom management issues (Kawamura, 1999). One way to pursue this is for teachers to read and listen to each other's stories and experiences and to reflect on their own teaching experiences (Schön, 1983). Through these reflective processes, teachers can personalize their knowledge and acquire an awareness that some teaching methods require higher management skills and techniques than others. Classroom management issues, however, cannot just be solved by acquiring a set of skills and techniques; teachers need to understand the academic as well as the social and cultural backgrounds of their students, and plan activity types with both academic and classroom management goals in mind. The participants in this study belong to a self-study group, in which they work to improve their own pronunciation and teaching methods. This type of self-study group is common amongst Japanese teachers to further develop their teaching skills. It is suggested that this type of safe and trusting environment is well suited to the sharing and exploring of classroom management issues.

In order to further facilitate this type of reflection, it would be useful if teachers had some frameworks with which to conceptualize classroom management so that they can analyze their own teaching practices. There is some literature available which could provide valuable practical advice for Japanese EFL teachers (for example, Brown, 1994; Lewis, 2002; Ur, 1996; Wright, 2005). Lewis (2002) is one author who recognizes that CLT 
poses classroom management difficulties and offers a useful framework for analysis. She argues that a classroom has to be managed from three perspectives: student motivation, external constraints, and a teacher's roles. By student motivation, she means student behaviours which reflect motivation, or lack thereof, to engage in language learning activity. The constraints include large class sizes, exam pressures, and ability differences among students. The teacher's roles include overseeing multiple groups instead of the whole class. In addition to Lewis's three perspectives, the current study proposes three slightly different, yet overlapping, ways to examine classroom management: spatial arrangements, teacherstudent roles, and the cognitive complexity of an activity. Teachers should be encouraged to find their own useful frameworks and apply them to their own teaching contexts. These types of conceptualizations can help teachers effectively examine the relationship between their own teaching styles, pedagogical outcomes, and classroom management.

\section{Conclusion}

The present study has described various experiences of classroom management among EFL teachers in Japan. The field of language teaching in Japan has emphasized and stressed academic goals and curriculum, but has failed to take into account one key educational issue: managing classes. The problem of classroom management becomes particularly difficult when teachers are encouraged to incorporate CLT activities into traditional teacher-fronted lessons. Culture-specific teacher training in which teachers can share their experiences with other teachers and engage in reflective process should be included in teacher training curricula. The present study also points out that much more research is needed to examine classroom management in language classrooms in the Japanese context. These research studies should further explore the relationship between classroom management and language teaching methodologies in order to help the many teachers who are struggling to teach English in changing circumstances.

\section{Acknowledgement}

I would like to thank all the teachers who participated in this study.

Keiko Sakui teaches English at Kobe Shoin Women's University. Her research interests include teacher beliefs and practices in classroom man- 
agement, learner motivation, and communicative language teaching. She has taught English and Japanese in the U.S. and New Zealand.

\section{Note}

This report is adapted from the author's unpublished doctoral thesis, Caught in a dilemma: Beliefs and practices of Japanese teachers of English (University of Auckland, New Zealand, 2004).

\section{References}

Allen, J. D. (1986). Classroom management: Students' perspectives, goals, and strategies. American Educational Research Journal, 23, 437-459.

Brouwers, A., \& Tomic, W. (2000). A longitudinal study of teacher burnout and perceived self-efficacy in classroom management. Teaching and Teacher Education, 16, 239-253.

Brown, H. D. (1994). Principles of language learning and teaching. Englewood Cliffs, NJ: Prentice Hall Regents.

Cothran, D. J., \& Ennis, C. D. (1997). Students' and teachers' perceptions of conflict and power. Teaching and Teacher Education, 13, 541-553.

Doyle, W. (1986). Classroom organisation and management. In M. C. Wittrock (Ed.), Handbook of research on teaching. (pp. 392-431). New York: Macmillan.

Doyle, W. (1990). Classroom management techniques. In O. C. Moles (Ed.), Student discipline strategies: Research and practice (pp. 113-127). New York: State University of New York Press.

Fenwick, D. T. (1998). Managing space, energy and self: Junior high teachers' experiences of classroom management. Teaching and Teacher Education, 14, 619631.

Gorsuch, G. (1998). Yakudoku EFL instruction in two Japanese high school classrooms: An exploratory study. JALT Journal, 20 (1), 6-32.

Jones, M. G., \& Vesilind, E. (1995). Preservice teachers' cognitive frameworks for class management. Teaching and Teacher Education, 11, 313-330.

Jones, V. (1996). Classroom management. In J. Sikula (Ed.), Handbook of research on teacher education. (pp. 503-521). New York: Macmillan.

Kagan, D. M. (1992). Professional growth among pre-service and beginning teachers. Review of Educational Research, 62 (2), 129-169.

Kato, T. (2001). Gakkyuu keiei ga konnan na gakkyuu no jittai [Realities of the classroom where management is difficult]. In T. Matsubara (Ed.), Resources of school psychology for teachers (pp. 21-31). Tokyo: Kyouiku Kaihatsu Kenkyuusho.

Kawamura, S. (1999). Gakkyuu hokai ni manabu [Learning from classroom collapse]. Tokyo: Seishin Shobo. 
Kawamura, S. (2000). Gakkyuu hokai yobou, kaifuku manual [Classroom collapse prevention and recovery manual]. Tokyo: Tosho Bunka.

Lamie, J. M. (2000). Teachers of English in Japan: Professional development and training at a crossroads. JALT Journal, 22 (1), 6-26.

Lee, I. (1996). Hong Kong primary teachers' perspectives on ELT. RELC Journal, $27,100-117$.

Lefstein, A. (2002). Thinking power and pedagogy apart-Coping with discipline in progressivist school reform. Teachers College Record, 104 (8), 1627-1655.

Lewis, M. (2002). Classroom management. In J. C. Richards \& W. A. Renandya (Eds.), Methodology in language teaching: An anthology of current practice (pp. 40-48). Cambridge: Cambridge University Press.

Li, D. (1998). "You plan and imagine": Teachers' perceived difficulties in introducing the communicative approach in South Korea. TESOL Quarterly $32(4), 677-701$.

McConnell, D. L. (2000). Importing diversity: Inside Japan's JET program. Berkeley, CA: University of California Press.

Monbukagakusho [Ministry of Education, Culture, Sports, Science, and Technology]. (1999). 'Gakushuu shidou youkou' [The course of study for foreign languages]. [On-line] Available: http://www.mext.go.jp/english/ shotou/030301.htm

Mulvey, B. (1999). A myth of influence: Japanese university entrance exams and their effect on junior and senior high school reading pedagogy. JALT Journal, $21,125-142$.

Okano, K., \& Tsuchiya, M. (1999). Education in contemporary Japan: Inequality and diversity. Cambridge: Cambridge University Press.

Patton, M. Q. (1990). Qualitative evaluation and research methods. Newbury Park, CA: Sage Publications.

Ran, C. (2001). Seikou gakkyuu no tokuchou to tsukurikata, shippai gakkyuu no fusegikata [Characteristics of successful classroom management and preventive strategies for unsuccessful management]. In T. Matsubara (Ed.), Resources of school psychology for teachers (pp. 64-75). Tokyo: Kyouiku Kaihatsu Kenkyuusho.

Sakui, K. (2004). Wearing two pairs of shoes: Language teaching in Japan. ELT Journal, 58 (2), 155-163.

Sato, K., \& Kleinsasser, R. C. (1999). Communicative language teaching (CLT): Practical understandings. The Modern Language Journal, 83, 494-517.

Sato, N. (1994). Nihon no kyoshi bunka no esunografi. [Ethnographic study of Japanese teachers' culture]. In T. Inagaki and Y. Kudomi (Eds.), Nihon no Kyoshi bunka [The culture of teachers and teaching in Japan] (pp. 125-139). Tokyo: Tokyo University Press.

Schön, D. (1983). The reflective practitioner: How professionals think in action. San Francisco: Jossey-Bass. 
Shimahara, N. K. (1998). The Japanese model of professional development: Teaching as craft. Teaching and Teacher Education, 14 (5), 451-462.

Strauss, A., \& Corbin, J. (1998). Basics of qualitative research: Techniques and procedures for developing grounded theory. Thousands Oaks, CA: Sage Publishers.

Tauber, R. (1999). Classroom management. London: Bergin \& Garvey.

Ur, P. (1996). A course in language teaching: Practice and theory. Cambridge: Cambridge University Press.

Wakazono, K. (2001). Gakkyuu keiei ga konnan na joukyou wo gutaiteki ni haaku suru [Understanding specific conditions of classroom management difficulty]. In T. Matsubara (Ed.), Resources of school psychology for teachers (pp. 38-45). Tokyo: Kyouiku Kaihatsu Kenkyuusho.

Wertsch, J. V. (1998). Mind as action. Oxford: Oxford University Press.

Williams, M., \& Burden, R. L. (1997). Psychology for language teachers: A social constructivist approach. Cambridge: Cambridge University Press.

Winograd, K. (2002). The negotiative dimension of teaching: teachers sharing power with the less powerful. Teaching and Teacher Education, 18 (3), 343-362.

Winograd, K. (2005). Good days and bad days: Teaching as a high-wire act. Lanham, MD: Scarecrow Education.

Wright, T. (2005). Classroom management in language education. New York: Palgrave Macmillan. 